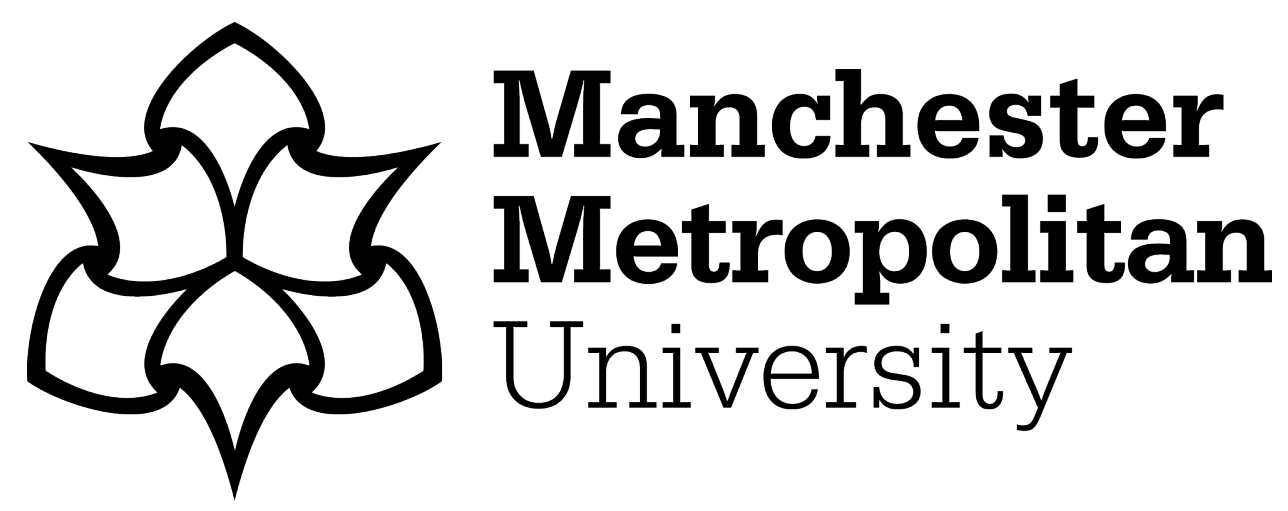

Olsson Rost, Kerstin ORCID logoORCID: https://orcid.org/0000-0002-73099721 (2019) The significance of the Welsh dimension: Pioneering of comprehensive education in Anglesey, circa 1930-1953. The Welsh History Review, 29 (3). pp. 436-460. ISSN 0043-2431

Downloaded from: https://e-space.mmu.ac.uk/621986/

Publisher: University of Wales Press

DOI: https://doi.org/10.16922/whr.29.3.4

Usage rights: Creative Commons: Attribution-Noncommercial-No Derivative Works 4.0

Please cite the published version 


\title{
THE SIGNIFICANCE OF THE WELSH DIMENSION: THE PIONEERING OF COMPREHENSIVE EDUCATION IN ANGLESEY, $c .1930-53$
}

\author{
ANNA OLSSON ROST \\ Manchester Metropolitan University
}

\begin{abstract}
Despite Anglesey's pioneering role as the first local authority in England and Wales to introduce a fully comprehensive education system (1953), it has received little attention in the historiography. It has often been assumed that 'economy and efficiency' were the predominant driving forces behind this new education policy, but this article acknowledges the complexities of the re-organization process and illustrates how political intervention at the local level was influenced by discussions related to the fact that Anglesey was both a rural and a Welsh local authority. This additional dimension to the pioneering of comprehensive schooling in Anglesey sheds new light on the rationale of the comprehensive scheme.
\end{abstract}

A range of different factors contributed to the favourable situation that led to the early establishment of a comprehensive education system in Anglesey in 1953. This article explores how far the Welsh context, within which the system was implemented, influenced educational developments in the county during the inter-war period. When other Local Education Authorities (LEAs) were only inclined, or allowed, to implement piecemeal systems of comprehensive or multilateral schooling, all of Anglesey's secondary schools were fully comprehensivized by the early 1950s. There was a distinct difference between multilateral and comprehensive schools. Whilst both types of schools catered for all children of secondary school age, pupils in multilateral schools would receive the type of education they were considered most 'suited' to (grammar, technical or modern depending on test results) in contrast to comprehensive schools where there were no entrance examinations. Anglesey was, therefore, the only fully comprehensivized LEA in England and Wales until the mid-1960s. From a Britain-wide perspective, the comprehensivization process started in the wake of the narrow Labour victory in the 1964 general election. The abolition of the 11- 
plus examination had been part of the Labour Party's manifesto since 1955, and once in government comprehensivization became a priority for the newly merged Department of Education and Science. ${ }^{1}$ In the summer of 1965 Anthony Crosland, the Education Secretary (1965-67) of the Wilson government, issued Circular 10/65. This was the Labour government's first official policy in favour of comprehensive schooling. Despite the party's stated commitment to a comprehensive education system, the circular famously 'requested' rather than 'required' LEAs to start planning for the reorganization of secondary schooling. ${ }^{2}$ However, a number of LEAs had already implemented different types of comprehensive schemes prior to 1965 , and unless the influence that these early schemes actually exerted on consequent developments in comprehensive education more widely is recognized, it becomes difficult to put subsequent schemes, often in Labour-led LEAs, into their proper historical contexts.

An exploration of the different influences that influenced educational developments in Anglesey during this time suggests that factors such as the timing, existing plans for reorganization, and social and economic conditions all affected the comprehensivization process. Furthermore, whilst decisions and actions of both local and central government allowed Anglesey's system to be realised, political intervention at the local level was highly influenced by discussions and perceptions related to the reality that Anglesey was both a rural and a Welsh local authority. This distinctiveness, and its significance, is the focus of this

\footnotetext{
${ }^{1}$ For the 1955 Manifesto, see "'Labour Party: 1955" Forward With Labour: Labour's Policy for the Consideration of the Nation', [http://www.politicsresources.net/area/uk/man/lab55.htm, accessed 27 November 2018].

${ }^{2}$ London, The National Archives (hereafter TNA), Ministry of Education, ED 147/827C, 'Circular 10/65: the Organisation of Secondary Education', 12 July 1965.
} 
article in which it is proposed that this additional dimension to the pioneering of comprehensive schooling in Anglesey sheds new light on the rationale of the scheme for secondary education that developed throughout the 1930s, and which was fully implemented by 1953. By extension, the article also makes a contribution to the wider historiography of the pioneering of comprehensive schooling in England and Wales by exploring the driving forces behind such an early reorganization plan for secondary education. By habitually viewing local policymaking as peripheral to 'real' government and decision-making at the national level, the true significance of local developments will remain obscured. For this reason it is imperative to make links between the local and national policymaking processes to enhance our understanding of the development of early comprehensive education systems. Therefore, this study puts at its centre an investigation of lesser-known local developments without losing sight of their interrelationship with the national context.

A host of factors contributed to the fertile ground that facilitated the realisation of a comprehensive education system in Anglesey by 1953. However, the Welsh dimension routinely interconnected with the wide range of influences that affected the reorganization process in the county. The conventional view that early comprehensive schemes emerged in rural local authorities solely as a result of practical and economic issues will then be investigated and evaluated. Finally, it will be demonstrated how developments in Anglesey cannot be analysed without due attention being paid to the Welsh context. A thorough analysis of the contemporary discussion and debate reveals the significance of a Welsh dimension to these proceedings, and its impact on the thinking of Anglesey's Education Committee, as well as on subsequent policymaking decisions during the 1940s. Part of this investigation will also focus on the inter-relationship between rhetoric and policy-making at the local level, and the way in which discourses of Welshness became an integral part of the 
Education Committee's rationale and justification for the reorganization of Anglesey's secondary schools.

\section{EDUCATIONAL REFORM}

A consequence of this is a relative shortage of revisionist scholarship on Welsh education history, and to date, no exclusive history of comprehensivization in Wales exists. Therefore, this article will provide some new insights into this aspect of Welsh education history and will illustrate the potential for further exploration of the field.

Educational developments in Wales had been both perceived and treated as decidedly distinct from those in England even prior to this period. The Aberdare Committee's report (1880) provided the foundations for the 1889 Intermediate Education Act, one of the first pieces of legislation of modern times to apply to Wales alone. This legislation resulted in the establishment of a system of publicly funded secondary schools in Wales thirteen years before similar developments beginning to take place in England. Furthermore, in 1907 there was a major devolutionary measure in the creation of the Welsh Department of the Board of Education. The Welsh Department was to be responsible for both the administration and inspection of education in Wales. ${ }^{3}$ Therefore, Wales' distinctiveness was not solely a question of perception, but by 1907 involved actual devolved powers (albeit that the offices remained in London and that the Welsh Department was regularly overruled by its parent body). This reinforced the individuality of education and schooling in Wales. The first

\footnotetext{
${ }^{3}$ Committee of Council on Education, Reports of the Commissioners of Inquiry into the State of Education in Wales, London, 1848, pp.11-112.
} 
permanent secretary of the Welsh Department was A. T. Davies, but perhaps more significant was the appointment of O. M. Edwards to the post of chief inspector in Wales. Edwards' strong commitment to the Welsh language and culture, and the role he believed these ought to play in Welsh education, spurred him on to attempt to influence both the curriculum and examination system in Wales. ${ }^{4}$

Thus, by the inter-war period, it was widely accepted that educational issues in Wales were distinct from those in England and that alternative solutions in relation to the reorganization of secondary education might receive a favourable reception in Wales. One of the most influential developments during this period was the publication of the Hadow Reports, between 1923 and 1933, and consequent moves towards educational reform. The Hadow Reports were commissioned to examine 'issues affecting not only the educational system, but also the general social and industrial organization of the country'. ${ }^{5}$ The most relevant feature of these reports was the recommendation that elementary education should no longer be provided in 'all-age' schools, but that all children should transfer to a different school at the age of eleven. Post-eleven instruction would not, however, be provided in the same type of schools for all pupils. Those children who were unsuccessful in the scholarship examination would transfer to Central Schools (still operating under the elementary code) where a more practical and vocational curriculum would be implemented ${ }^{6}$ Central Schools had been

\footnotetext{
${ }^{4}$ See, for example, Jones and Roderick, A History of Education in Wales, pp. 112 and 113 and H. Davies, O. M. Edwards (Cardiff, 1988), pp. 96-104.

${ }^{5}$ Board of Education, Report of the Consultative Committee on the Education of the Adolescent (London, 1926), p. 2.

${ }^{6}$ Board of Education, Report of the Consultative Committee on the Education of the Adolescent (London, 1926), p. 2.
} 
established after the Education Act of 1918. The Act stipulated that LEAs could provide 'more advanced' instruction to older or more academically gifted elementary pupils in these types of schools. Central Schools gradually grew in number, and by the 1930s the Board of Education insisted on LEAs establishing such schools. ${ }^{7}$

Although these reports were only consultative, they visibly influenced the Board of Education's thinking and policies during the 1930s. Several bold suggestions were made, for example, the proposition that the school-leaving age should be extended by a year from the age of fourteen to fifteen. ${ }^{8}$ However, although this suggestion was rejected by the Board of Education at this time, it remained a live issue throughout the 1930 s. ${ }^{9}$ On the other hand, Hadow's recommendation to implement a stricter separation between primary and senior education in elementary schools (at the age of eleven) was deemed practicable, and LEAs were expected to start making arrangements for such reform during the $1930 \mathrm{~s} .{ }^{10}$ Anglesey's

\footnotetext{
${ }^{7}$ L. Andrews, The Education Act, 1918 (London, 1976).

${ }^{8}$ Board of Education, Report of the Consultative Committee on the Education of the Adolescent (London, 1926), p. 148.

${ }^{9}$ For a thorough analysis of the raising of the school-leaving age in Britain and its consequences, see S. Cowan, T. Woodin and G. McCulloch, Secondary Education and the Raising of the School-Leaving Age: Coming of Age? (New York, 2013).

${ }^{10}$ For details on the Ministry of Education's response to the Hadow Report and further insights into its implications at the local level, see Rodger Moore, 'Hadow reorganization in a community setting: A. H.
} Whipple and the William Crane School in Nottingham, 1931-1938', History of Education, 30, 4 (2001), 379-99. 
response to the demand for 'Hadow reorganization' along these lines was to produce a scheme for a multilateral education system as early as $1931 .^{11}$

During the 1930s, further demands were made of local authorities. The Hadow Reports and the 1936 Education Act required LEAs to submit proposals for reorganization, particularly after the decision in 1936 to increase the school-leaving age to fifteen, which was to be implemented by 1939. However, this initiative was postponed at the start of the war and it was not realised until 1947. Nonetheless, it was in response to this projected rise of the school-leaving age that Anglesey's Education Committee proposed another multilateral scheme for secondary education in 1936 , one that was very similar to the plans produced in 1931. However, the Development Plan experienced delays and opposition from the Board of Education, and had not been realised by the time of the outbreak of the Second World War. Unsurprisingly, the reorganization of secondary education was no longer a priority during the war years. Nonetheless, with the publishing of the Beveridge Report (1942) and the surge in demands for social welfare reform, legislative change for education was also forthcoming. A new Education Act was passed in 1944 and it saw the Board of Education succeeded by the Ministry of Education. The Act also legislated for 'secondary education for all', making secondary education free and available for all age-appropriate children.

\footnotetext{
${ }^{11}$ The 1931 Development Plan and subsequent plans submitted to the Board of Education in the wake of the rejection of this early multilateral proposal were all highly influential for the scheme that was eventually approved by the Ministry in 1946.
} 
The perceived peculiarities of the Welsh education system generated calls for differentiated treatment in regards to the reorganization of secondary education in the wake of the 1944 Education Act. Because the Welsh system had evolved independently of the English system since 1889, the introduction of the 1944 Education Act was viewed as a more contentious issue in Wales than in England. With the introduction of the Act, the individuality of the Welsh education system was in effect being infringed upon. ${ }^{12}$ The 1889 Act had allowed secondary education to become more accessible in Wales, and this was believed to have had a positive effect on social mobility in a way which remained unfeasible in England. ${ }^{13}$ There was, therefore, a sense that developments in the Welsh education system were not just distinct, but also provided more wide-spread and equal educational opportunities than were available in the English system.

The 1944 Act did not legislate for the introduction of the tripartite system (the creation of three separate types of secondary schools: grammar, secondary modern and technical schools). The question of how to organize secondary schools in the wake of the Education Act was, in fact, left open, but the idea of three separate 'types' of child, and therefore three different kinds of secondary school to cater for these different types of children, was already

\footnotetext{
${ }^{12}$ See, for example, Jones and Roderick, A History of Education in Wales, pp. 87 and 89, and D. Gareth Evans, A History of Wales 1906-2000 (Cardiff, 2000), p. 248.

${ }^{13}$ For comments on the distinctive Welsh system after 1889 , and for its superiority in terms of social mobility, see, for example: G. E. Jones, 'Policy and power: one hundred years of local education authorities in Wales', 343-358; Jones and Roderick, A History of Education in Wales, p. 89; and Kenneth. O. Morgan, Modern Wales: Politics, Places and People (Cardiff, 1995), p. 204. For grammar school entry, see, for example, Joan Simon, 'Report from south Wales', Forum, 1, 2, (1959), 49-51. For a general view of a superior system being threatened after 1944, see, for example, John Davies, A History of Wales (London, 2007), p. 617.
} 
fairly well-established and was supported by prominent educationists as well as by many politicians at the time of the passing of the 1944 Education Act. ${ }^{14}$

Since the Act left open different options for reorganization to LEAs, several Welsh local authorities presented multilateral schemes to the Ministry of Education - Anglesey being one of them. Multilateral solutions for Wales were also advocated by teaching unions, sections of the Labour Party, and the Federation of Education Committees. ${ }^{15}$ This was partially due to the rurality of large parts of Wales, but also because socio-economic, cultural and linguistic differences were considered to make large parts of Wales unsuitable for a differentiated system of secondary education. However, the Welsh Department was not willing to sanction multilateral solutions for the whole of rural Wales, as had been suggested by the National Union of Teachers of Wales, Undeb Cenedlaethol Athrawon Cymru (UCAC). ${ }^{16}$ Many Welsh local authorities preferred to implement tripartite or bipartite systems, while others were denied their requests for multilateral solutions altogether, despite the Welsh Department's declaration in favour of such experimental schemes in Wales on a case-by-case basis. During the 1950s, a majority of LEAs implemented some type of differentiated system, rendering Anglesey's fully comprehensive scheme a solitary exception into the mid-1960s. The Board of Education would go so far as to allow a mixture of provision in Wales, and the fact that

\footnotetext{
${ }^{14}$ Simon refers to the development of this tenet in the '...economically and socially stagnant period of the interwar years', B. Simon, Education and the Social Order, p. 158.

${ }^{15}$ Jones, Controls and Conflicts in Welsh Secondary Education, pp. 182-3; R. Webster, School and Community in Rural Wales, (Aberystwyth, 1991), p. 45.

${ }^{16}$ Both the Federation of Education Committees and UCAC requested special considerations to be taken into account for the case of Wales after the 1944 Education Act. See, for example, Jones, Controls and Conflicts in Welsh Secondary Education, pp. 182-3 and Webster, School and Community in Rural Wales, p. 45.
} 
Wales, particularly rural Wales, had already been considered a practicable area for trialling multilateral solutions, favoured the affirmative approval of Anglesey's Development Plan by the newly established Ministry of Education (which officially approved it in 1948).

\section{RURALITY AND COMPREHENSIVE SCHOOLING}

General histories of educational developments during the twentieth century have often considered rural areas' early experimentation with comprehensive schooling in the immediate post-1944 period as simply a case of the most 'economical and efficient' solution for particular local authorities. It is revealing that, despite Anglesey's significant presence in the contemporary debate about comprehensive education, the island's scheme has often either been only briefly commented upon in the historiography, or has been completely absent from it. ${ }^{17}$ Anglesey's system has tended to be mentioned sporadically, often without in-depth analyses of its rationale, pioneering role, or how prominently the scheme actually featured in the contemporary educational debate during the 1950 s and 1960 s. ${ }^{18}$

\footnotetext{
${ }^{17}$ See, for example: C. Benn and C. Chitty, Thirty Years On: Is Comprehensive Education Alive and Well or Struggling to Survive? (London, 1996); G. E. Jones, The Education of a Nation; I. G. K. Fenwick, The Comprehensive School, 1944-1970 (London, 1976); Melissa Benn, School Wars (London, 2011), p. 49; A. C. Kerckhoff, K. Fogelman, D. Crook and D. Reeder, Going Comprehensive in England and Wales: A Study of Uneven Change (London, 1996), p. 19; C. Benn and B. Simon, Half Way There: Report on the British Comprehensive School Reform (2 ${ }^{\text {nd }}$ edn, Harmondsworth, 1972), pp. 44-5; Jones and Roderick, A History of Education in Wales, p. 148; D. Rubinstein and B. Simon, The Evolution of the Comprehensive School, 1926$1972\left(2^{\text {nd }}\right.$ edn, London, 1973), pp. 46-7.

${ }^{18}$ A. Olsson Rost, "'Britain is watching this school experiment, Anglesey leads the way". A forgotten pioneer? Anglesey's comprehensive system, circa 1953-1965', Anglesey Antiquarian Society Journal, 2015-2016 (2016), 27-45. Fearn suggested that: 'If, as has often been stressed, comprehensive schools in rural areas such as
} 
Therefore, the majority of early pioneering schemes in LEAs such as Anglesey or the Isle of Man have not been explored in much depth. ${ }^{19}$

Thus, the history of comprehensivization has predominantly, and perhaps understandably, been composed of analyses of national policymaking, as driven by central government and the Labour Party. Local developments have often, by necessity considering the scope of enquiry, been treated as side-shows to policymaking nationally. Consequently, local rationales and nuanced have sometimes been lost or misunderstood. This can present a problem, since unless early developments in rural local authorities are incorporated into the wider scholarship, there is a risk of generating an urbanized and Labour Party-centric narrative of comprehensivization which does not fully reflect contemporary developments prior to the mid-1960s. This investigation of the rationale at the local level in Anglesey, therefore, provides a complementary narrative, where a more comprehensive insight into local developments reveals the significance of the Welsh context. Such examination also reveals the implication of developments during the 1920s and 1930s for the design of the scheme that was unofficially approved by the Ministry of Education as early as 1946 . This demonstrates the importance of investigating developments considerably earlier than the mid1960s (when central government endorsed the policy of comprehensive education) in order to understand the driving-forces behind the pioneering of comprehensive schooling.

\footnotetext{
Anglesey ... were created for practical as much as for ideological reasons, subsequent cases, for example, in London and Coventry, definitely owed more to ideology'; quoted in E. Fearn, 'The politics of local reorganization', in R. Lowe (ed.), The Changing Secondary School (Lewes, 1989), p. 37

${ }^{19}$ Anglesey is not mentioned at all in, for example, Benn and Chitty, Thirty Years on; Jones, The Education of a Nation; and Fenwick, The Comprehensive School 1944-1970.
} 
In the 1980 s, Fearn commented on the historiography of comprehensivization: '[T]here is a relative shortage of case studies of rural and semi-rural areas ... as opposed to studies of urban areas', ${ }^{20}$ and this assessment remains pertinent today. ${ }^{21}$ Considering the much more extensive attention paid to urban and Labour-led local authorities, it appears as if rural comprehensive schemes have been viewed as not being politically motivated and, thus, might have appeared rather less interesting as subjects for further investigation. It is certainly the case that the London County Council's School Plan, approved by the ministry in 1950, has been afforded much more attention in the literature than most other early comprehensive schemes. ${ }^{22}$ This is perhaps unsurprising considering its radical and political rationale (and also the size and importance of the authority compared to many other LEAs). The history of comprehensive schooling in England and Wales has often been written by supporters of this type of schooling, with a particular interest in the ideological driving-forces behind comprehensive education, and therefore also the party political dimension of policymaking in education. However, this means that early schemes in more peripheral local authorities where party politics might not have dominated local government, have been over-shadowed by

\footnotetext{
${ }^{20}$ Fearn, 'The politics of local reorganization', in R. Lowe (ed.), The Changing Secondary School (Lewes, 1989), pp. 36-7.

${ }^{21}$ I. G. K. Fenwick and A. J. Woodthorpe, 'The reorganisation of secondary education in Leeds: the role of committee chairmen and political parties', Aspects of Education, 22 (1979), pp. 18-28; A. G. Geen, Decision Making and Secondary Education A Case Study (Cardiff, 1986); D. Crook, 'Local authorities and comprehensivisation in England and Wales, 1944-1974', Oxford Review of Education, 28, 2/3 (2002), 247-60. ${ }^{22}$ Simon, Education and the Social Order, pp. 110, 130-1, 170; S. Maclure, A History of Education in London 1870-1990 (London, 1990).
} 
more politically radical schemes, many of which were implemented in urban settings later on during the late 1960s and into the 1970s.

This has left the history of early pioneers of comprehensive education relatively unexplored. Even though most accounts of this period acknowledge rural pioneers, only limited insights into their rationales or their potential significance to wider educational developments have been provided to date. The assumption has been that because of issues related to practicalities in regards to the reorganization of secondary education in rural areas, ideological considerations did not feature in these LEAs. Benn's observation is not an uncommon one: 'Britain's first purpose-built comprehensive, in Anglesey, opened in 1949 although it owed its existence to practicality rather than politics; it was simply impossible to sustain a two- or three-tier structure in an outlying area'. ${ }^{23}$ Similarly, Crook concluded that Anglesey 'was permitted to go fully comprehensive as a special case', and that the Ministry's acceptance of rural schemes was 'for reasons more to do with economics than with education' ${ }^{24}$

Developments in Anglesey during the 1930s and 1940s provide a necessary contextual background for understanding the comprehensivization process in Anglesey. A multilateral solution to reorganization had already been endorsed by the Education Committee in 1931, and the numerous other Development Plans that were devised throughout the 1930s were all based on this original scheme. These plans were submitted to the Board of Education at different stages during the negotiation process, but none of them were granted the approval of

\footnotetext{
${ }^{23}$ Benn, School Wars, p. 37.

${ }^{24}$ Crook, 'Local authorities and comprehensivisation in England and Wales', p. 248.
} 
the Board of Education. Despite the fact that the Board of Education would not sanction any of the authority's multilateral plans during the 1930s, the fundamentals of the Development

Through a detailed examination of the role played by practicalities, rhetoric, and the Welsh context, the rationale of the Education Committee can be carefully unpicked to reveal a nuanced picture of the attitudes behind the scheme. Even purely practical issues of reorganizing secondary education in a rural area such as Anglesey were inextricably linked to the Welsh context of the local authority. The case for the introduction of a multilateral system, as made by the local authority and put forward to the Board of Education during the 1930s, did certainly use practicalities as one of its justifications. Multilateral schools would allow the authority to provide different 'types' of secondary education within one school building, hence addressing the issue of providing appropriate education to senior pupils in such a sparsely populated area. It was also felt that a system of Central Schools, meaning alternative schools for pupils of secondary school age who did not pass the scholarship examination, would be 'impracticable except at Holyhead' both due to the island's low population and the fact that the relative number of pupils entering secondary schools was already high. ${ }^{25}$ Some reference was also made to economic benefits, with the suggestion that the demands for the education of adolescents contained in the Hadow Report could be

\footnotetext{
${ }^{25}$ It was considered feasible to maintain a Central School in Holyhead. See London, TNA, Ministry of Education, ED 142/1, 'Circular 144', 16 June 1947. Since the town's population was large enough (recorded as 10,700 in the 1931 Census), see HMSO, Census of England and Wales 1931: Counties of Anglesey and
} Caernarvon, pt. I (London, 1933) and the fact that a Central School already existed in Holyhead since 1934, undoubtedly affected the LEA's stance on this issue. 
fulfilled through a multilateral scheme 'without unnecessary duplication of equipment' ${ }^{26}$ It was also pointed out that with the introduction of the multilateral system 'the need for expenditure on new Technical, Central, and Non-Selective Central Schools no longer remains', indicating that there might be some financial benefits to a multilateral scheme. ${ }^{27}$ Apart from these two brief comments, however, potential economic benefits connected with multilateralism were not specifically addressed in the Development Plan. Correspondence also shows that the concerted view of the Board of Education was that a multilateral scheme would, if anything, be more expensive than a differentiated system. ${ }^{28}$ The scheme was, however, promoted much more robustly on practical grounds compared to strictly economic considerations. The evidence suggests that while practical and economic considerations were part of the rationale for the scheme, other factors were also influential in the LEA's decision to continue determinedly to defend and promote its policy throughout the 1930 s and beyond, and the Welsh context of the local authority was inextricably linked to the practical aspects of the rationale for the scheme. The already existing sentiment that alternative solutions for (particularly rural) Wales might be preferable meant that there was a Welsh dimension to these purely practical arguments.

\section{THE WELSH CONTEXT IN THE 1930s}

Support for the multilateral scheme was often expressed in relation to Welsh contexts, illustrating the significance of the Welsh dimension in the development of Anglesey's

\footnotetext{
${ }^{26}$ London, TNA, ED 16/827: Anglesey Education Committee (hereafter AEC), 'Proposal for Educational Development in Anglesey', 17 September 1936.

27 Ibid.

${ }^{28}$ London, TNA, Board of Education, ED 35/6804: 'Interview memorandum', 17 November 1936.
} 
comprehensive scheme. This rhetoric was associated with different aspects of 'Welshness', and was closely connected to views about Welsh identity and attitudes. The virtually legendary reputation of the Welsh people's passion for education fed into the wider debate during the 1930s, as exemplified by a speech on secondary education in Wales by Oliver Stanley (President of the Board of Education) in 1935. ${ }^{29}$ Stanley pointed out that, despite the political ambiguity educational reorganization seemed to generate, Wales was nonetheless 'a land which had never thought it right or fashionable to decry the value and advantages of education'. ${ }^{30} \mathrm{He}$ also emphasized that Wales had demonstrated a constant desire for 'higher and higher education', something Stanley attributed to the 1889 Intermediate Education Act. ${ }^{31}$ He stressed that 'the Welsh people' believed the state should care for elementary as well as secondary education, and that this 'zeal' for secondary education had never diminished in Wales' ${ }^{32}$ These perceptions of Welsh attitudes towards education, and the way in which the history of education in Wales was regularly referred to in order to justify a different approach compared to England, were commonplace during this period.

Significant importance was attributed to the role of the Intermediate Education Act, and the consequent opportunity for all children to benefit from a secondary school education in Wales - particularly noticeable due to the academic emphasis in many of these Intermediate Schools. The Welsh people's 'passion for education' and their belief in the importance of a good education were often referred to in the public debate during the 1930s and beyond.

\footnotetext{
${ }^{29}$ Holyhead and Anglesey Mail, 4 October 1935.

30 Ibid.

${ }^{31}$ For Stanley's speech on secondary education in Wales, see Holyhead and Anglesey Mail, 4 October 1935.

${ }^{32}$ Holyhead and Anglesey Mail, 4 October 1935.
} 
Casual remarks, such as those made in the Holyhead and Anglesey Mail in 1936 declaring that 'the Welsh race had had a great passion for education for generations,' formed part of a Welsh identity, and also fed into the rhetoric of the Anglesey Education Committee during this period. ${ }^{33}$ In fact, historic contexts of educational developments in Wales were still mentioned in the national press during the 1960s when there was a surge of interest in the origins and development of comprehensive education in Anglesey as a result of central government's endorsement of comprehensive reorganization. ${ }^{34}$

However, the significance of this professed dedication to the virtues of an academic education in Wales constituted more than mere musings about the past. The widespread belief that the 1889 Intermediate Education Act had set Welsh educational developments on a separate path to that of England, allowing a higher proportion of pupils in Wales to benefit from free secondary education notably earlier than children in England, is highly noteworthy. ${ }^{35}$ This sentiment also influenced the rhetoric of those leading educational developments in Anglesey at this time. E. O. Humphreys, who had become Anglesey's Director of Education in 1935, commented in 1936 that '[W]e in Wales ... have democratic ideals in education' and '[I]f we believe in Secondary education for all, let us say so'. ${ }^{36}$

\footnotetext{
${ }^{33}$ Holyhead and Anglesey Mail, 7 February 1936.

${ }^{34}$ In 1965 The Times declared that: '[T] here is the traditional passion of Welsh parents for the education of their children' and 'they [the people of Anglesey] see the value of education and are prepared to pay for it', The Times, 3 April 1965. Similarly, in The Observer (in 1964) it was reported that '[I]f a child had ability in Wales, his parents would always find a way to get him to grammar school', The Observer, 6 December 1964.

35 The Aberdare Committee (1880) was a government-appointed committee with the brief to 'inquire into the state of ... education in Wales'; cited in Jones and Roderick, A History of Education in Wales, p. 87.

${ }^{36}$ Ibid.
} 
Humphreys' statement emphasized the distinction of the Welsh belief, in contrast to the perceived English sentiment, that secondary education should be available to all. It is important to make the distinction between senior education and secondary education. Senior education was the type of schooling provided in elementary schools, and increasingly in Central Schools, for pupils over the age of eleven, whilst secondary education was the schooling received in selective grammar schools. Humphreys also expressed his conviction that supporters of secondary education for all should speak out. The comment on the specific Welsh 'democratic ideals in education' indicates the ideological rhetoric that was used to justify educational reform in Anglesey. Sir Ben Bowen Thomas (Permanent Secretary to the Welsh Department of the Ministry of Education, 1945-63), who knew Humphreys well, described the Director as 'a man of strong views', who

blamed the loss of initiative in Welsh education on the iron hand of the English connection .... He had a sense of mission deriving from a belief that Welsh education in the earlier days had enjoyed greater freedom and that so-called 'national policy' had been allowed to sap the vigour and strength of local responsibility. To him, widespread interest in education was a fact of life in Wales. It had always been so, and this justified its development at its own pace and in its own way. ${ }^{37}$

Bowen's assessment of Humphreys' views further reinforces the proposition that local decision-makers employed this Welsh narrative to construct a case for an alternative approach to educational reform in Anglesey. It also indicates Humphreys' negative attitude towards the 'iron hand' of the English connection, and the belief that reforms imposed nationally had caused adverse effects on both the freedom of Welsh education and the powers of local authorities. Developments during the 1930s and 1940s also provide evidence of how

\footnotetext{
${ }^{37}$ B. Bowen Thomas, 'E. O. Humphreys - the man who created comprehensives', Education (1975), 658.
} 
these attitudes informed the Education Committee's actions in practice with its adherence to its own policy of secondary, not central, education for all - despite the disapproval of the Board of Education.

The influence of the Welsh dimension, as discussed above, is evident in the development of practical policy in Anglesey during the 1930s. For example, in an interview with the Board of Education in 1937 the LEA representative suggested that 'Wales, being a more democratic country [than England] with fewer class distinctions, required ... one Type[sic] of school for all senior children' and in August 1938 the feeling was that:

the Authority [Anglesey] differed fundamentally from the Board. The latter divided children into two classes, those who might become leaders and those who would only be followers. The second class were to go to senior schools ... [but] it was impossible at the age of 11 to determine into which of these groups any child should be placed. The Authority wished the majority of their children to be given a chance in the Secondary School. ${ }^{38}$

The practice of admitting high numbers of pupils to the secondary schools, analysed below, was therefore not purely practical, but interlinked with views connected to the Welsh way of life and identity, particularly in contrast to what was perceived as England's hierarchical society. Among some of the LEA's representatives at least, this policy was also a matter of providing more equal opportunities in relation to the type of education that would be made available to all children over the age of eleven. It was felt that those who would be refused

\footnotetext{
${ }^{38}$ For the comments on Wales being more 'democratic' than England, see, London, TNA, Board of Education, ED 35/6808, 'Interview Memorandum', 3 May 1937. For the statement on the differences in opinion between the Board of Education and the LEA, see, London, TNA, ED 35/6804: Board of Education, 'Interview Memorandum', 24 August 1938.
} 
entry into secondary schools at the age of eleven would be unfairly treated, and that the aspiration should be to allow as many pupils as possible access to secondary schools something which was attempted in practice during the 1930s.

The only satisfactory solution for Anglesey would, therefore, be to allow all children entry to secondary schools, and for these schools to be adapted to 'meet the needs of all pupils over 11 years of age'. ${ }^{39}$ The Education Committee maintained its support for a multilateral solution throughout the 1930 s, and was plain in its intent: 'The Committee is definitely of the opinion that the development of Post Primary Education in Anglesey should be based on the principle of Multilateral Secondary Schools. ${ }^{, 40}$

Hence, whilst there were certainly practical and, to some extent, economic reasons behind the LEA's rationale for a multilateral solution during the 1930s, to deem Anglesey's persistent pursuit of a multilateral system (from 1947 labelled a comprehensive system) solely a case of practicality without an ideological rationale, would be erroneous. Practical action taken during the 1930s in aid of achieving this goal emphasizes both the ideological rationale behind the scheme, and the influence of the Welsh context on the Education Committee's handling of the running of its secondary schools.

\footnotetext{
${ }^{39}$ Llangefni, AA, WA 1/42: Sub-Committee Reorganisation of Schools, 1929-30, 'Minutes', 15 January 1930.

${ }^{40}$ London, TNA, AEC, ED 16/827, 'Proposal for Educational Development in Anglesey', 17 September 1936.
} 
It was the Hadow Reports, and the consequent calls for local authorities to consider ways to reorganize school provision, that had prompted Anglesey's Education Committee to produce their original multilateral plan. Already in 1918 the Education Act had encouraged the establishment of Central Schools, and by the latter half of the 1920s there already existed both selective and non-selective Central Schools (particularly in urban areas in both England and Wales). Part of the Hadow reorganization drive during the 1930s was the establishment of more such schools in England and Wales in order to implement a clearer division between junior and senior elementary school pupils at the age of eleven. ${ }^{41}$ Post-eleven instruction would, therefore, be provided in different types of schools for different 'types' of pupils. Those pupils who were not successful in the scholarship examination would transfer to Central Schools (still operating under the elementary code) where a more practical and vocational curriculum would be implemented. ${ }^{42}$ The removal of all-age elementary schools (often referred to as 'all-age' schools) in line with Hadow's recommendations, alongside the establishment of Central Schools, became the Board of Education's preferred solution to the issue of reorganization of secondary education during this period. The creation of Central Schools generated debates in Wales for both ideological and geographical reasons. There was a concern that Central Schools would become second-class institutions, and geographically, many areas did not have sufficient numbers of pupils to sustain separate schools. Therefore, the development of Central Schools was slow and even in the relatively populous county of Glamorgan, only nine central schools had opened by 1936 . However, this proved to be a

\footnotetext{
${ }^{41}$ Board of Education, The Education of the Adolescent, pp. 52-5.

${ }^{42}$ Ibid.
} 
drawn-out process, particularly in Wales, and it was not completed before the outbreak of the Second World War. ${ }^{43}$

The significance of the Welsh context, as far as reorganization in Anglesey during the 1930s was concerned, is apparent. There had been a Departmental Committee on the Organization of Secondary Education in Wales set up in the wake of the 1918 Education Act, and the committee reported back to the Board of Education in 1920. Their assessment was that a widespread rejection of Central Schools (or Senior Schools) was present in Wales as a whole. ${ }^{44}$ It was noted that such resistance in Wales was primarily because of a desire to provide compulsory secondary (rather than central) education, free of charge, for all children up to the age of sixteen. ${ }^{45}$ This tenet was considered to be a particularly Welsh standpoint, and links between the development of Intermediate Schools and a more general reluctance to accept differentiated secondary education were often drawn.

In the case of Anglesey, this unwillingness to provide senior education in Central Schools, in contrast to the LEA's expressed preference for secondary education for all pupils over the age of eleven, is highly significant. The Education Committee was staunchly devoted to its multilateral plans throughout the 1930s, and a thorough investigation of the minutes of meetings and correspondence between the LEA and the Board of Education reveals that there

\footnotetext{
${ }^{43}$ Jones and Roderick, A History of Education in Wales, p. 129.

${ }^{44}$ Board of Education, Report of the Departmental Committee on the Organisation of Secondary Education in Wales (London, 1920).

${ }^{45}$ Board of Education, Report of the Departmental Committee on the Organisation of Secondary Education in Wales (London, 1920).
} 
existed an underlying and unswerving dedication to the concept of secondary education for all. So, despite early schemes, like the one in Anglesey, subsequently being criticized for what was perceived as a lack of ideological fervour, these sentiments were certainly prominent during the negotiations with the Welsh Department in the 1930s. ${ }^{46}$ In light of such criticism, the steadfast and vociferous support for the provision of secondary education for all of Anglesey's children is a significant revelation. Anglesey's policy might not have sprung from the kind of political radicalism that characterized the London County Council (LCC) during the 1950s, or that of urban Labour-led local authorities such as Manchester and Liverpool later on. Nonetheless, the rationale for the initiative in Anglesey was far from devoid of socio-political aims. In fact, in an internal Board of Education memorandum, Anglesey's Director of Education (E. O. Humphreys) was described as having become 'bewitched by the slogan "Secondary education for all"' and he was believed to have convinced his Education Committee 'that no pupil ought to be refused admission to a secondary school' ${ }^{47}$

Humphreys had already been an avid supporter of multilateral schooling prior to his appointment as Director of Education in 1935. His conviction was thus in line with the local authority's existing policy in regards to secondary education in Anglesey. Humphreys

\footnotetext{
${ }^{46}$ A majority of contemporary commentary on early comprehensive schools was provided by educationists who were staunch supporters of comprehensive education. A sense of disappointment can be detected clearly in their assessments. See, for example: R. Pedley, 'Comprehensive schools today: an interim survey (1)', Education, 8 October, 1954, 518; and London, Institute of Education University of London Archives: Brian Simon Papers, SIM/1/18 , 'Conference paper: What Schools are For: Retrospect and Prospect to Lancashire County Council', 16 February 1977.

${ }^{47}$ London, TNA, Board of Education, ED 35/6804, 'Internal memorandum', 12 July 1938.
} 
expressed his admiration of the LEA for having 'stood firm' in its belief in the multilateral system in the wake of the Hadow Report and articulated his respect for the Development Committee's 1931 report and its values. ${ }^{48}$ Therefore, although Humphreys became the key figure in future deliberations with the Board of Education, and he was viewed by the Board of Education as the main driving force behind the island's obstinate reluctance to reorganize schools along the lines advocated by the Board of Education, he was not a lone instigator of multilateral education in Anglesey. The Education Committee was already committed to the idea of multilateral education by 1935 . The intention behind the appointment of a multilateral supporter such as Humphreys (quite a well-known educationist locally at the Normal College in Bangor), was undoubtedly to secure a Director of Education who would continue an established strategy. Therefore, the interpretation that the Director had somehow hoodwinked the Education Committee to support the policy on secondary education is somewhat simplified.

The appointment of Humphreys coincided with the beginning of the authority's drawn-out wrangling with the Board of Education in respect of the Hadow reorganization during the 1930s. He also continued to be the leading figure in the communication with the Ministry of Education throughout the planning period of the 1940s and finally during the implementation of the new education system in the early 1950s. Humphreys was also a key participant at the numerous meetings and interviews held with representatives from the Board of Education in attempts to negotiate a compromise in regards to secondary education in Anglesey. However, whilst there is no doubt of Humphrey's advocacy for multilateral schooling and 'secondary education for all', and his extensive involvement in the planning for this policy indicates

\footnotetext{
${ }^{48}$ Holyhead and Anglesey Mail, 7 February 1936.
} 
wholehearted support for this sentiment from the Education Committee as a whole, and in several cases this was vociferously expressed. ${ }^{49}$

Thus, the Welsh Department's assessment that the Education Committee was fully devoted to the goal of providing 'secondary education for all', was accurate. The goal throughout the 1930s was to provide as many pupils as possible with a secondary education. The establishment of a multilateral scheme would allow for the provision of secondary school places for a higher proportion of children, and this was at the heart of the rejection of the creation of Central Schools. The idea of creating Central Schools that would run alongside the authority's existing grammar schools would not fulfil the Education Committee's vision. The LEA made continuous efforts to acquire increased grants from the Board of Education with a view to provide free secondary education for all pupils. However, with no increased grants forthcoming, the scheme had to be abandoned due to the lack of funding for such ambitious plans. Instead, a gradual programme to extend existing provision for senior pupils both in secondary schools and elementary schools was envisaged. Nonetheless, in 1931 the principle of free secondary education for all was described as 'an ideal that should not be lost sight of by those concerned with education in the County', and it did indeed inform educational developments throughout the 1930 s and beyond. ${ }^{50}$

\footnotetext{
${ }^{49}$ See, for example, London, TNA, Board of Education, ED 35/6808, 'Interview memorandum', 3 May 1937 and ED 35/6804, 'Interview memorandum', 24 August 1938.

${ }^{50}$ Llangefni, AA, WA 4/18: AEC, 'Proposal for Reorganisation', 2 July 1931.
} 
As has been pointed out earlier, the first multilateral plan was rejected by the Board of Education in 1931, as was the (very similar) Development Plan which was submitted in 1936. This did not, however, dissuade the Education Committee in its continued pursuit of its goal. Despite the setback of the rejection in 1936, a circular issued by central government in January of that year provided some hope. The circular established that no upper limit would be set for Special Places for pupils attending secondary schools. Means-tested Special Places for grammar schools had been introduced in 1932 to replace the existing 'free places'. The fact that there was no upper limit for the means-tested places from 1936 meant that the LEA was free to admit any number of pupils from the elementary schools to its secondary schools, as long as those pupils were of secondary school age, had passed the scholarship examinations and qualified in accordance with the means-testing. This was seen as an opportunity for the Education Committee to extend pupil numbers in secondary schools despite still not having received the approval for their plans from the Board of Education. ${ }^{51}$ Therefore, notwithstanding the rejection of the multilateral plan, the LEA was hopeful that the allowance for unlimited special places could be used to its advantage by providing secondary places to as many pupils as possible. ${ }^{52}$

The way in which the Education Committee tried to carry this out, despite the disapproval of the Board of Education, was by simply continuing to admit high numbers of pupils to its secondary schools. This was, in effect, a way of adhering to its own plans but without necessarily labelling secondary schools multilateral. Internal communications reveal how the

\footnotetext{
${ }^{51}$ Jones and Roderick, A History of Education in Wales, p. 132.

${ }^{52}$ Board of Education Circular 1444 (January 1936), see AEC, London, TNA, ED 16/827: 'Proposal for educational development in Anglesey', 17 September 1936.
} 
Board of Education's patience with Anglesey's sustained tendency to overcrowd its secondary schools and its refusal to reorganize the island's elementary schools was running out. Sir Wynn Wheldon (Permanent Secretary of the Welsh Department, 1933-45) was convinced that Anglesey 'did not want to reorganise' and that its aim was solely to gain 'exceptionally high admissions to their secondary schools'. ${ }^{53}$ He also pointed out that the allowance for one-hundred per cent Special Places was not intended as a free pass for LEAs to admit excessive numbers of pupils to their secondary schools. Especially, he emphasized, where the accommodation was not sufficient to admit such numbers, as was the case in Holyhead. ${ }^{54}$ He was also certain that the LEA's intention was to pursue its policy regardless of the Board's disapproval, pointing out that:

The main difficulty in coming to an agreement lay in the fact that the Authority were attempting to press on with their own policy and to present the Board with a fait a compli by offering admissions to large numbers in September next ... the Authority ... had done nothing to meet the Board's wishes on the reorganisation question. ${ }^{55}$

Wheldon's assertion was certainly justified in view of the endurance of this approach towards the question of how many (or how big a proportion of) pupils to admit to the island's secondary schools. The LEA was able to manage the numbers of entries to the schools via its control of the entrance tests, and it was aided by the allowance since 1936 for LEAs to provide a hundred per cent Special Places in secondary schools. ${ }^{56}$

\footnotetext{
${ }^{53}$ London, TNA, ED 16/827, AEC, 'Proposal for educational development in Anglesey', 17 September 1936.

${ }^{54}$ London, TNA, ED 35/6808, BoE, 'Notes from deputation, Shire Hall, Llangefni', 24 August 1938.

${ }^{55}$ London, TNA, ED 16/82, AEC, 'Proposal for Educational Development in Anglesey', 17 September 1936.

${ }^{56}$ London, TNA, ED 35/6808, Board of Education, 'Notes from deputation, Shire Hall, Llangefni', 24 August 1938.
} 
The Welsh Department also noted that the reason for the big proportion of pupils in attendance at Anglesey's secondary schools was the relatively low pass grade of the scholarship examination, which was fixed at 33.3 per cent. ${ }^{57}$ The LEA's own report on the allocation of Special Places in 1939 clearly recognized the link between the number of pupils passing the test and the desire to admit high numbers of pupils to the island's secondary schools. ${ }^{58}$ However, with the threat of the withdrawal of funding having been issued by central government in 1938, the Education Committee was forced to back down, and a tentative agreement was reached towards the latter half of 1938. The negotiated arrangement involved the concentration of senior pupils in selected elementary schools as a first step towards the creation of Central Schools, but virtually none of the plans were implemented prior to 1939 and the outbreak of war. This left Anglesey more or less completely 'unreorganized' prior to the introduction of the new Education Act in 1944.

The Development Plan that was submitted in the mid-1940s was largely unchanged from earlier schemes. However, the response from the newly-established Ministry of Education was considerably different from to the rather hostile reception of the Board of Education a decade or so previously. The Development Plan was informally approved in 1946, and by 1953 all secondary schools on Anglesey had been fully comprehensivized. While the approval of the multilateral scheme in the mid-1940s must be considered a significant success for the Education Committee, it did not constitute novel educational thinking. The ideas that underpinned the plan of 1936 originated from the very early 1930 s when multilateral

\footnotetext{
${ }^{57}$ London, TNA, ED 35/6804, Board of Education, 'Internal note', 12 July 1938.

${ }^{58}$ London, TNA, ED 77/134, AEC, 'Examination for the award of special places in secondary schools: report of an investigation held on 17th, 18th, and 19th January', 1939.
} 
organization had first been considered, and the fact that the scheme was labelled 'comprehensive' by 1947 was dictated by the Ministry of Education's definition rather than being based on the initiative of the LEA per se. The change in terminology, as implemented by the Education Committee, was prompted by a central government circular (June 1947) where it was proposed that 'a comprehensive school means one which is intended to cater for all the secondary education of all the children in a given area without an organization into three sides'. ${ }^{59}$ Since Anglesey's schools would not be divided into 'three sides', but would provide secondary education to all age-appropriate children within each catchment area, it was decided to refer to schools as comprehensive rather than multilateral henceforth. ${ }^{60}$

\section{CONCLUSION}

It is clear how the 'typically Welsh' sentiment of 'secondary education for all' influenced both the rhetoric and actions of Anglesey's Education Committee during this period. There were clear parallels between the rejection of a differentiated system of secondary education in the form of Central Schools, and the LEA's practices in relation to entrance examinations and the number of pupils admitted to Anglesey's grammar schools. This feeling was also reflected in the rhetoric of the discussion around multilateralism during this time. Whilst practicalities were certainly an influential factor in the LEA's case for a multilateral solution, they were also often linked to the wider debate about the special case of Wales.

\footnotetext{
${ }^{59}$ London, TNA, Ministry of Education, ED 142/1, 'Circular 144', 16 June 1947.

${ }^{60}$ Llangefni, Anglesey Archives (Hereafter AA), WA/1/39: Post-War Development of Education Sub Committee (hereafter PWDESC), 'Minutes', 27 November 1947.
} 
This investigation into the developments that led up to the implementation of a fully comprehensive system in Anglesey in 1953 suggests that the rationale for the scheme was not solely based on practicalities - as has often been proposed in existing scholarship. Whilst efficiency and economy undoubtedly played a part in the development of the scheme, as well as for the Ministry of Education's decision to approve the plans, other factors also need to be taken into consideration. The early submission of the Development Plan, which was achieved as a result of the existing blueprint from the plans of the 1930s, meant that the informal approval of the scheme was forthcoming as early as August 1946. Two years later, in September 1948, D. R. Hardman (Parliamentary Secretary to the Minister of Education) laid the foundation stone for the new comprehensive school in Amlwch, providing purpose-built accommodation for the secondary school. ${ }^{61}$ At this time, when Anglesey was constructing the first ever purpose-built comprehensive school in England and Wales (a Grade II* listed building today) many other LEAs were still only in the early development stages of their Development Plans. ${ }^{62}$ Furthermore, comprehensivization and the abolition of the 11-plus examination became an increasingly politicized issue; therefore, there is no doubt that the early submission of the plan increased its chances of being approved by the Ministry of Education.

\footnotetext{
${ }^{61}$ Llangefni, AA, WA/16/1, Amlwch Couny School, 'Minutes', 12 October 1948.

${ }^{62}$ Some further examples of other LEAs' progress with their multilateral or comprehensive plans were Swansea, the West Riding, Bristol and Leicestershire. See, for example, Dinah Evans, 'The dynamics of Labour Party politics in Swansea 1941-1964' (unpublished PhD thesis, University of Wales, Bangor, 2007), 251-3; Kerckhoff, Fogelman, Crook and Reeder, Going Comprehensive in England and Wales, pp. 118, 85-7; K. J. Donald, 'The reorganization of secondary education in Leicestershire, 1947-1984', in R. Lowe (ed.), The Changing Secondary School (Lewes, 1989), pp. 20-36.
} 
Additionally, the lack of progress made in reorganizing secondary education in Anglesey prior to 1944 - a consequence of the drawn-out wrangling between the LEA and the Welsh Department during the 1930s - also made Anglesey an area of priority in the eyes of the Ministry of Education by the mid-1940s.$^{63}$ Whilst not overlooking these important factors, it is essential to consider the interrelationship between these influences and that which has been described as 'the Welsh dimension' in this article. It was, indeed, the protracted discussions with the Welsh Department, in defence of the admission policy in line with what was considered the typically Welsh ideal of secondary education for all, that resulted in Anglesey being considered a priority area for reorganization in the wake of the 1944 Education Act. Furthermore, the early submission of the Development Plan in the wake of the Education Act was only possible as a result of the already existing multilateral plan, which had simply been re-worked and re-submitted to the newly established Ministry of Education.

This article has demonstrated that discussions in Anglesey's Education Committee and in the wider educational debate were influenced by the belief that Welsh sentiments were different to those that could be found in England. This was particularly prominent in relation to the provision of secondary education. The lack of progress in regards to Hadow reorganization in Anglesey was a direct consequence of the resolute desire by the Education Committee to adhere to its policy of admitting as many pupils as possible to its grammar schools, a policy that was justified by the Director on the grounds of Welsh 'democratic ideals in education'.

\footnotetext{
${ }^{63}$ For the Ministry's wish to grant Anglesey's plan early treatment, see Llangefni, AA, WA/1/39, PWDESC 'Minute book: letter from the Ministry of Education', 4 December 1946. For comments in the Ministry’s internal correspondence, see London, TNA, BD 7/1, Ministry of Education, 'Internal notes', 1946.
} 
Thus, the Welsh context had a perceptible impact on the rhetoric attached to the discussions about reorganization that took place between the Education Committee and the Welsh Department. The perception among members of the Education Committee, repeatedly expressed, was that Welsh educational ideals did not support the policy of a differentiated system of secondary schooling. It was this belief that underpinned the pursuit of the distinctive policy to admit a very high number of children to Anglesey's grammar schools throughout the 1930s and into the 1940s. A very similar discourse is also discernible in the relation to the Education Committee's support for multilateral schooling.

These findings, therefore, suggest that there is a case for revising our understanding of the driving forces behind the rationale for this early comprehensive scheme. In contrast to, for example, the Labour-led LCC Development Plan or the later reorganization plans of urban LEAs during the 1960s and 1970s, Anglesey's rationale did not make specific reference to any particular political motives. However, this does not mean that there was a complete lack of ideological justification for the scheme all together. Whilst the LCC's development plan has been described 'as much a political polemic as a statement of educational intent', ${ }^{64}$ Anglesey's scheme was certainly neither pitched, nor perceived, as being 'political' in this sense. Nonetheless, by further exploration of local contexts, it becomes clear that the comprehensivization process was certainly more complex than simply providing a practical solution in a rural area. Anglesey's Education Committee's dogged support for a multilateral (later labelled comprehensive) system of secondary education reveals the role of perceptions of Welshness in the practical decision-making processes. In order to provide a more nuanced and complete picture of the broader history of comprehensivization, therefore, the histories of

\footnotetext{
${ }^{64}$ Kerckhoff, Fogelman, Crook and Reeder, Going Comprehensive in England and Wales, p. 60.
} 
early pioneering schemes, such as that in Anglesey, need to be integrated more fully into the wider historiography. This article provides a starting point for such a project. 